\title{
PERAN DOSEN DALAM MENGEMBANGKAN KARAKTER MAHASISWA
}

\author{
Markus Masan Bali \\ Character Building Development Center, BINUS University \\ Jln. Kemanggisan Ilir III No. 45, Kemanggisan - Palmerah, Jakarta Barat 11480 \\ masanpetun@yahoo.com
}

\begin{abstract}
Character building education today is non-negotiable for the character building of students in college. One important element in the character education of students in college is lecturers. Lecturers have an important role in character education in college. In carrying out the main task of the Tri Dharma University, which is doing the teaching, research, and community service, a lecturer does a process of internalization of the noble values which later become the campus culture. Lecturers are the main actors in the formation and development of the students' character with exemplary. Before educating the students' character, a lecturer at least has the character corresponding to the main task of a teacher. In addition, a very important role of which is not overlooked is to educate, teach, train, guide, and evaluate.
\end{abstract}

Keywords: lecturer's role, character building education, Tri Dharma University

\begin{abstract}
ABSTRAK
Pendidikan karakter dewasa ini merupakan suatu yang menjadi harga mati bagi pembentukan karakter mahasiswa di perguruan tinggi. Salah satu unsur penting dalam pendidikan karakter mahasiswa di perguruan tinggi adalah dosen. Dosen memiliki peran penting dalam pendidikan karakter di perguruan tinggi. Dalam melaksanakan tugas utama Tri Dharma Perguruan Tinggi, yaitu melakukan pengajaran, penelitian, dan pengabdian kepada masyarakat, seorang dosen melakukan proses internalisasi nilai-nilai luhur yang kemudian menjadi budaya kampus. Dosen menjadi aktor utama dalam pembentukan dan pengembangan karakter para mahasiswa dengan keteladanan. Sebelum mendidik karakter para mahasiswa, seorang dosen paling tidak memiliki karakter yang sesuai dengan tugas utama seorang dosen. Selain itu, peran dosen yang amat penting yang tidak dilupakan adalah mendidik, mengajar, melatih, membimbing, dan mengevaluasi.
\end{abstract}

Kata kunci: peran dosen, pendidikan karakter, Tri Dharma Perguruan Tinggi 


\section{PENDAHULUAN}

Sabtu, 23 Februari 2013 penulis melihat nama para mahasiswa yang kedapatan menyontek pada waktu ujian akhir semester ganjil di papan pengumuman. Setelah pulang, penulis berpikir, ada apa dengan perilaku menyontek ini? Apakah pendidikan karakter perlu ditingkatkan lagi atau peraturan dari Binus perlu diperketat lagi? Sejauh mana pengaruh pendidikan karakter terhadap para mahasiswa? Apakah selama pembelajaran Character Building hanya sebagai sebuah persyaratan saja atau sebuah pembelajaran untuk kehidupan? Sejauh mana peran dosen untuk mengajak atau memberi perhatian kepada karakter mahasiswa yang mau gampang saja dan mau yang instan?

Jika dicermati, kasus menyontek yang dilakukan mahasiswa paling tidak disebabkan oleh budaya malas dan ingin serba instan. Artinya, mahasiswa yang bersangkutan hanya ingin mendapatkan nilai bagus namun tidak mau belajar. Jika kasus seperti ini dibiarkan, bukan tidak mungkin makin banyak mahasiswa yang akan menyontek. Benih-benih korupsi akan tumbuh subur di masyarakat setelah para mahasiswa ini menyelesaikan kuliah. Pihak universitas atau para pendidik harus menghentikan praktik-praktik seperti ini. Agar para mahasiswa tidak lagi menyontek pada waktu ujian, perlu dicari cara-cara lain.

Melihat kasus menyontek tersebut, penulis menyadari bahwa upaya pendidikan karakter di Universitas Bina Nusantara sebenarnya tidak hanya dibebankan kepada dosen mata kuliah CB, tetapi kepada setiap dosen. Para dosen (tidak hanya dosen character building) perlu menyadari peran penting dalam menjalankan tugas dan fungsi pokoknya di perguruan tinggi dengan didukung oleh para tenaga kependidikan, infrastruktur, dan berbagai program akademik dan nonakademik. Intinya, seorang dosen adalah seorang pendidik. Pendidik menjadi kata kunci di perguruan tinggi karena seorang dosen tidak hanya mentransfer ilmu pengetahuan atau keterampilan, tetapi juga memberi teladan, motivasi, dan spirit untuk para mahasiswa. Dengan demikian, mahasiswa dapat tumbuh dan berkembang menjadi insan yang seimbang secara akademik dan mental (hardskills dan soft skills).

Dosen mengemban tugas utama yang dikenal dengan Tri Dharma Perguruan Tinggi, yaitu kegiatan pendidikan, penelitian, dan pengabdian kepada masyarakat. Salah satu tugas dari Tri Dharma yaitu pendidikan mengisyaratkan kepada para dosen agar tidak hanya mengajar materi atau mentransfer pengetahuan. Selain itu, para dosen juga menginternalisasikan nilai-nilai atau karakter kepada para mahasiswa yang sangat menentukan keberhasilan mahasiswa pada masa depan.

Internalisasi nilai-nilai atau karakter yang dilakukan oleh dosen kepada para mahasiswa membutuhkan pemahaman, keterampilan, dan kompetensi mengenai karakter itu sendiri. Namun, satu hal yang penting, seorang dosen mampu memancarkan dari dalam dirinya karakter-karakter mulia yang dapat diteladani oleh para mahasiswa. Keteladanan memiliki bahasa atau pesan tersendiri yang sangat menguat dalam diri mahasiswa. Keteladanan tidak banyak berbicara atau memberi penjelasan tentang tip atau pengetahuan menjadi baik dan benar. Akan tetapi, para mahasiswa dapat melihat dan menyaksikan sendiri seorang dosen dalam berbicara, bertindak, dan bahkan mindset dari dosen sendiri yang terpancar lewat cara mengajarnya. Singkatnya, untuk internalisasi nilai-nilai atau karakter kepada para mahasiswa, seorang dosen memiliki karakter yang kuat sehingga ketika mengajar di kelas memiliki daya atau "roh" untuk menggerakkan mahasiswa untuk meniru dan mengikuti yang disampaikan. Salah satu hal yang perlu diingatkan terus menerus bahwa menyontek adalah bakal dari korupsi. Apa jadinya jika seorang dosen membiarkan mahasiswa menyontek pada waktu ujian?

Lalu, karakter dosen yang bagaimana? Dosen yang berkarakter bertujuan untuk membuka mata hati mahasiswa untuk belajar, agar mampu hidup dengan nilai-nilai atau karakter di tengah masyarakat. Dosen yang berkarakter memiliki ciri-ciri sebagai berikut: memiliki komitmen, kompeten, 
kerja keras, konsisten, sederhana, memiliki kemampuan berinteraksi, melayani secara maksimal, cerdas, ikhlas dalam bekerja, menjaga diri dan kehormatan, menjadi teladan bagi peserta didik.

Seorang dosen yang memiliki karakter seperti yang disebutkan dapat dikatakan sebagai sebuah modal untuk melakukan proses pembelajaran karakter di perguruan tinggi. Di sini, dosen memiliki peran yang cukup penting dalam membangun dan mengembangkan karakter para mahasiswa. Untuk itu, dalam paper ini penulis secara khusus menekankan peran penting dosen dalam pendidikan karakter di perguruan tinggi. Pertama penulis akan membahas tentang pendidikan karakter sebuah kaharusan untuk zaman sekarang, menyadari tugas dosen, mengajar dan belajar berkarakter, dan sebagai pamungkas tentang kontribusi dosen dalam pendidikan karakter.

\section{METODE PENELITIAN}

Metode penelitian yang digunakan dalam penulisan ini adalah penelitian kepustakaan. Artinya, peneliti menggunakan literatur (kepustakaan), baik berupa buku, catatan, maupun laporan hasil penelitian sebelumnya. Namun dalam penelitian ini, penulis menggunakan literatur berupa buku dan catatan, serta pengamatan penulis ketika berada di kampus.

Pengumpulan data tidak langsung ditujukan pada sebuah penelitian, namun melalui dokumen. Dokumen yang digunakan dapat berupa buku harian, surat pribadi, laporan, notulen rapat, catatan khusus dalam pekerjaan sosial dan dokumen lainnya. Jadi semua dokumentasi diposisikan setara tergantung ketersambungan dengan topik utama. Data yang dipakai oleh penulis dalam artikel tentang peran dosen dalam mengembangkan karakter mahasiswa adalah laporan hasil menyontek yang dibuat oleh Kampus Universitas Bina Nusantara yang ditempel di depan ruang akademisi, buku, dan juga artikel yang diambil dari Internet. Penulis melakukan identifikasi wacana dari laporan, buku, makalah atau artikel, jurnal, dan informasi lainnya tentang peran dosen dalam membimbing dan membina para mahasiswa sehingga tindakan menyontek yang merupakan satu hal yang bertentangan dengan karakter yang diajarkan.

Setelah mengidentifikasi data yang diperoleh, penulis menyimpulkan tentang masalah yang dikaji. Dan dalam hal ini data yang sudah ada kemudian dianalasis. Analisis yang digunakan adalah analisis deskriptif yakni data yang dikumpulkan berupa kata-kata, gambar, dan bukan angka. Hal ini disebabkan oleh adanya penerapan metode kualitatif. Selain itu, semua data yang dikumpulkan dimungkinkan menjadi kunci terhadap apa yang sudah diteliti. Dengan demikian, peran dosen dalam mengembangkan karakter mahasiswa ini berisi kutipan dan pengolahan data untuk memberikan gambaran tentang penyajian laporan tersebut.

\section{HASIL DAN PEMBAHASAN}

Pengembangan karakter bukanlah sebuah pelajaran seperti mata kuliah atau mata pelajaran yang lain. Pengembangan karakter adalah sebuah pembelajaran tentang kehidupan, maka pembelajaran karakter terus berlangsung sepanjang hidup kita. Pembelajaran karakter sebaiknya dimulai dari pendidikan tingkat dasar sampai di perguruan tinggi. Di sini perguruan tinggi mampu memberikan pembelajaran karakter kepada para mahasiswa. Maka peran dosen sangat penting dalam pembelajaran karakter. Dosen tidak hanya mengajar materi pembelajaran, tetapi juga dapat menjadi panutan dan juga contoh dalam karakter serta mampu membuka mata hati para mahasiswa untuk melaksanakan nilai-nilai kehidupan. 


\section{Pentingnya Pendidikan Karakter di Perguruan Tinggi}

Fenomena atau kasus menyontek yang dilakukan oleh para mahasiswa sebenarnya menjadi pekerjaan rumah bagi para dosen. Fenomena ini menunjukkan bahwa pendidikan karakter yang diajarkan belum menyentuh kehidupan praktis mahasiswa. Para mahasiswa yang menghidupi budaya instan sebenarnya telah menunjukkan degradasi moralitas. Mereka hanya mencari kesenangan sendiri tanpa memahami sebuah perjuangan, kesabaran, kesetian, dan nilai kejujuran.

Untuk memperbaiki moralitas dan karakter mahasiswa, maka pendidikan karakter yang telah diajarkan bukan hanya sebagai sebuah teori pembelajaran tetapi sebuah praktik kehidupan mahasiswa ketika belajar di kampus. Sudah saatnya pendidikan karakter di perguruan tinggi berfungsi membendung degradasi moralitas atau karakter dan membentuk karakter mahasiswa yang kokoh guna menghadapi berbagai tantangan masa depan. Pendidikan karakter pun menjadi daya pendorong bagi para mahasiswa untuk menjadi intelektual muda bangsa yang memiliki kepribadian unggul, sebagaimana dimuat dalam undang-undang pendidikan nasional.

Perguruan tinggi memiliki dua unsur utama, yaitu dosen dan mahasiswa. Kedua unsur ini perlu memiliki orientasi ke arah perkembangan budaya akademik. Keduanya pun diikat dalam etika akademik yang tumbuh dari nilai-nilai luhur dan berujung pada terbentuknya budaya akademik. Menurut Santoso (2011), patut dipahami bahwa latar belakang keseluruhan unsur yang ada dan lebih dicermati lagi dinamika eksternal kampus. Dalam pelaksanaannya inti kegiatan perguruan tinggi adalah Tridharma Perguruan Tinggi, sehingga semua kegiatan pendidikan, penelitian, dan pengabdian kepada masyarakat dilaksanakan dengan berkarakter. Namun, untuk melaksanakan kegiatan pendidikan berkarakter, diperlukan pembiasaan kehidupan keseharian di kampus yang menjadi budaya kampus. Pembiasaan itu akan tampak dalam berbagai kegiatan kemahasiswaan dalam berbagai bidang seperti olahraga, karya tulis, kesenian, dan lain-lain.

Pembiasaan seperti yang telah disebutkan, sebenarnya merupakan pengejawantahan dari nilainilai luhur total dalam budaya akademik. Norma kegiatan akademik yang dirujuk di Indonesia bersubjek kepada mahasiswa yang melakukan proses pembelajaran. Wujudnya berupa kegiatan kurikuler, kokurikuler, dan ekstrakurikuler. Beban kegiatan akademik tersebut seutuhnya harus proporsional, produktif, dan positif. Contoh yang mudah dipahami adalah untuk tidak melakukan tindakan menyontek atau plagiat (Wibowo, 2013).

Melalui pendidikan karakter di perguruan tinggi yang efektif, diharapkan terlahir model pendidikan yang bermakna bagi mahasiswa, tidak sekadar memberikan pengetahuan kognitif, tetapi juga juga afektif, dan konatif pada kelompok bahan ajar keahlian dan keterampilan.

Wibowo (2013) secara terperinci menjelaskan bahwa pendidikan karakter di perguruan tinggi mempunyai beberapa fungsi sebagai berikut. Pertama, pembentukan dan pengembangan potensi mahasiswa artinya upaya untuk membentuk dan mengembangkan manusia dan warga Negara Indonesia berpikiran, berhati, dan berperilaku baik sesuai dengan falsafah Pancasila. Kedua, perbaikan dan penguatan yaitu upaya memperbaiki karakter manusia dan warga Negara Indonesia yang bersifat negatif dan memperkuat peran keluarga, satuan pendidikan di perguruan tinggi, masyarakat, dan pemerintah, untuk berpartisipasi dan bertangung jawab dalam mengembangkan potensi manusia atau warga negara, menuju bangsa yang berkarakter, maju, mandiri, dan sejahtera. Ketiga, sebagai alat penyaring, yaitu upaya memilah nilai-nilai bangsa, dan menyaring nilai-nilai budaya bangsa lain yang positif untuk manjadi karakter manusia dan warga negara Indonesia seutuhnya. Melalui proses penyaringan karakter ini, diharapkan para mahasiswa menjadi bagian dari bangsa ini yang memiliki karakter yang mulia, intelektual dan bermartabat. 
Melihat fungsi pendidikan karakter tersebut, penerapan atau pelaksanaan pendidikan karakter di perguruan tinggi merupakan suatu harga mati. Pertanyaannya, apakah pendidikan karakter itu hanya dilakukan dalam satu mata kuliah saja atau terintegrasi dalam setiap mata kuliah? Yang mesti diperhatikan, pembelajaran pendidikan karakter hendaknya dilakukan pada semua perkuliahan. Di sini, pendidikan karakter tidak perlu diajarkan pada mata kuliah khusus, sebab pendidikan karakter sesungguhnya sudah dapat ditemukan dalam mata kuliah tertentu yang dianggap memiliki muatan pendidikan karakter lebih kental. Pengelompokan mata kuliah ini seperti pendidikan Kewarganegaraan, Bahasa dan Sastra, dan Seni. Oleh karena itu, pendidikan karakter di perguruan tinggi hendaknya menjadi tanggung jawab setiap dosen. Dengan demikian setiap dosen mempunyai kewajiban membentuk karakter mahasiswa dan tidak hanya dibebankan kepada dosen mata kuliah tertentu atau program studi tertentu.

Namun, pendidikan karakter juga dapat diajarkan melalui mata kuliah khusus. Di sini pendidikan karakter secara tegas dan terbatas dipandang sebagai sebuah mata kuliah yang diajarkan. Pendidikan karakter hanya bisa diwujudkan secara efektif dengan membuat mata kuliah khusus yang diajarkan kepada para mahasiswa sama seperti mata kuliah pada umumnya. Mata kuliah ini didesain sedemikian rupa sehingga materi, metode, dan evaluasinya dapat dipakai sebagai pedoman untuk menilai tingkat pembentukan karakter dalam diri para mahasiswa. Pendidikan karakter seperti ini terwujud secara nyata di dalam sebuah mata kuliah seperti mata kuliah character building, agama, dan juga pendidikan Pancasila. Mata kuliah ini menjadi bagian integral dan penting dalam pembentukan karakter mahasiswa. Mata kuliah ini dijadikan sebagai mata kuliah wajib yang harus diikuti oleh para mahasiswa. Mata kuliah ini dianggap penting karena dapat menentukan mahasiswa tersebut lulus atau tidak dalam perkuliahan. Oleh karena itu, peran dosen untuk mata kuliah tertentu seperti dosen character building sangat diperlukan. Dalam hal ini menginternalisasikan nilai-nilai karakter dalam pembelajaran, mengevaluasi pembelajaran tentang nilai-nilai tersebut di setiap akhir pembelajaran untuk menentukan mahasiswa tersebut layak lulus atau tidak.

\section{Dosen Berkarakter}

Pendidikan karakter di perguruan tinggi tidak dapat ditawar lagi dewasa ini. Salah satu unsur yang terlibat dalam pendidikan karakter adalah dosen. Dalam proses pembelajaran di kelas seorang dosen tidak hanya menyampaikan materi pembelajaran, tetapi juga harus menjiwai seluruh proses pembelajaran dengan nilai-nilai luhur seperti kejujuran, keterbukaan, saling menghargai, tanggung jawab, dan sebagainya. Di sini seorang dosen dapat dikatakan sebagai dosen yang berkarakter. Dengan kata lain, seorang dosen tidak saja dituntut memiliki kemampuan intelektual, tetapi juga memiliki kemampuan emosional dan spiritual. Tujuannya adalah agar dapat membuka mata hati mahasiswa yang belajar agar memiliki kemampuan intelektual yang dapat dipercaya dan juga memiliki karakterkarakter bangsa yang berasalah nilai-nilai luhur. Seorang dosen dapat dikatakan berkarakter jika memiliki ciri-ciri sebagai berikut.

\section{Memiliki Komitmen}

Di sini seorang dosen mempunyai tekad yang kuat. Tekad seorang dosen adalah melaksanakan tugas dan tanggung jawabnya sebagai seorang pendidik. Seorang dosen yang memiliki komitmen yang tinggi akan memiliki ketajaman visi, rasa memiliki, dan bertanggung jawab terhadap tugas dan panggilan yang diembannya sebagai pendidik. Komitmen menjadi seorang dosen akan terlihat dalam visi dan misinya. Seperti dikatakan Ki Hajar Dewantara, komitmen seorang dosen/guru adalah misi kemanusiaan, mencerahkan dan membebaskan bangsa dari kebodohan. Ketika mengemban tugas ini, segala macam tantangan harus dihadapi dengan tegar dan kuat. Jika mau menjadi dosen, disarankan harus memiliki komitmen untuk mencerahkan para mahasiswa akan nilai-nilai luhur bangsa. 


\section{Memiliki Kompetensi}

Seorang dosen dianggap kompeten jika mampu melaksanakan pembelajaran, dan memecahkan berbagai masalah guna mencapai tujuan pendidikan. Seorang dosen kompeten ditandai dengan keahlian di bidangnya, menjiwai profesi yang dimiliki, memiliki kompetensi pedagogik, kepribadian, sosial, dan profesional.

\section{Memiliki Semangat Kerja Keras}

Sebagai seorang dosen, kerja keras merupakan suatu keharusan terutama dalam melaksanakan tugas-tugasnya, khususnya dalam internalisasi pendidikan karakter bagi para mahasiswa. Seorang dosen dianggap memiliki semangat untuk bekerja keras jika bekerja dengan ikhlas dan sunggguhsungguh, bekerja melebihi target, dan produktif.

\section{Konsisten}

Konsisten sebenarnya menjadi tanda bahwa dosen telah menjiwai dan melaksanakan profesinya. Konsistensi seorang dosen dapat terlihat dalam kata-kata dan juga tindakannya.

\section{Memiliki Jiwa Sederhana}

Kesederhanaan sebenarnya tidak identik dengan kemiskinan. Seorang dosen dapat dikatakan sederhana jika mampu mengaktualisasikan seseuatu secara efektif dan efisien. Kesederhanaan seorang dosen terpancar lewat perilaku seperti bersahaja, tidak bermewah-mewah baik penampilan maupun model hidup, tidak berlebihan dalam mempergunakan apa saja, tepat guna artinya memanfaatkan segala sesuatu secara tepat, dan memiliki kegundaan atau kontribusi positif.

\section{Kemampuan Berinteraksi}

Seorang dosen juga dituntut memiliki kemampuan berinteraksi secara dinamis dengan para mahasiswa secara emosional dalam mencapai tujuan pembelajaran.

\section{Menjaga Diri dan Kehormatan}

Seorang dosen yang profesional tidak akan terpengaruh segala macam tawaran seperti kenaikan gaji, pangkat, kedudukan, atau iming-iming materi. Menjaga kehormatan dosen dapat dilakukan dengan meningkatkan kompetensi diri, membekali diri dengan keterampilan serta senantiasa menjaga tutur kata, pikiran, dan perbuatan negatif.

\section{Menjadi Teladan bagi Mahasiswa}

Teladan memiliki makna sebagai sesuatu dari proses mengajar, hubungan interaksi selama proses pendidik, yang kemudian hari atau masa depan mahasiswa menjadi contoh yang ditiru dan digugu. Dosen yang teladan bukanlah dosen yang menjaga wibawa atau image saja, tetapi keteladanan dosen dapat terpancar lewat perilakunya. Tutur kata, sikap, dan perbuatan merupakan sebuah komunikasi yang efektif dalam pendidikan karakter. Secara psikologis, pengaruh perilaku adalah pengaruh bawah sadar peserta didik, yang akan muncul kembali saat ia melakukan aktivitas dalam bersikap, bertindak atau menilai sesuatu pada dirinya dan orang lain.

Keteladanan seorang dosen akan tertanam dalam benak peserta didik jika dalam interaksi dosen dan para mahasiswa dilakukan secara profesional. Proses pemindahan keteladanan diri, pengetahuan diri, dan perilaku profesional seorang dosen kepada peserta didik, dibutuhkan teknik yang disebut dengan teknik mendampingi, menolong, dan mendidik. 
Selain karakter-karakter tersebut, menurut UNESCO, seperti yang dikutip Zamroni (2011) dari Rynder (2006) disimpulkan bahwa ada enam dimensi karakter yang bersifat universal bagi dosen. Enam dimensi karakter tersebut sebagai berikut. Pertama, dapat dipercaya (trustworthiness); seorang dosen dapat menjadikan dirinya dapat dipercaya jika memiliki kejujuran, integritas, loyalitas, dan reliabilitas. Dosen seperti ini tidak mungkin berbohong, mengutamakan institusinya sendiri daripada institusi lainnya, dan konsisten antara kata dan perbuatan. Kedua, respek (respect); seorang dosen yang memiliki karakter ini akan selalu menghormati dan menghargai orang lain tanpa memandang latar belakang yang menyertainya, termasuk latar belakang keilmuan, menjunjung tinggi harkat dan martabat rekan sejawat dan para mahasiswa, memiliki sikap toleransi yang tinggi, dan mudah menerima semua mahasiswanya dengan tulus. Ketiga, tanggung jawab (responsibility); seorang dosen yang memiliki karakter bertanggung jawab senantiasa akan menunjukkan dirinya dan yang telah diperbuat. Watak ini akan melahirkan kerja keras dan bekerja sebaik mungkin untuk mencapai prestasi terbaik. Keempat, adil (fairness); seorang dosen memiliki watak ini akan tampak ketika akan memberikan penilaian terhadap para mahasiswanya. Ia tidak akan membeda-bedakan mahasiswa yang satu dengan mahasiswa yang lain. Pemberian nilai pun harus berdasarkan kriteria objektif dan juga berdasarkan aspek-aspek yang disepakati. Kelima, peduli (caring); seorang dosen yang memiliki watak peduli akan mempergunakan kehalusan budi dan perasaan sehingga dapat berempati terhadap para mahasiswanya, baik ketika mengalami kesulitan dalam perkuliahan, maupun mencapai prestasi yang baik. Keenam, menjadi warga negara yang baik (citizenship); seorang dosen adalah warga negara juga. Maka dari itu, seorang dosen perlu memahami tugas dan tanggung jawabnya sebagai warga negara yang baik.

Dari penjelasan di atas, dapat dikatakan bahwa dalam pendidikan karakter dituntut satu hal bahwa seorang guru atau dosen harus memiliki karakter. Karakter bukan sekadar hafalan tetapi sebuah keteladan hidup memberi pengaruh lewat keteladan hidup. Keteladanan hidup dosen akan menjadi komunikasi yang efektif dalam pendidikan karakter.

\section{Peran Dosen Membangun dan Mengembangkan Karakter Mahasiswa}

Pada bagian awal telah dibahas tentang tugas utama seorang dosen yaitu melaksanakan Tri Dharma Perguruan Tinggi, yaitu melaksanakan pendidikan dan pengajaran, melaksanakan penelitian, dan melaksanakan pengabdian kepada masyarakat. Sebagai pendidik, seorang dosen mempunyai peran penting dalam mengembangkan karakter para mahasiswanya. Menurut Madjid dalam Wibowo (2013), dosen memiliki lima peranan pokok, yaitu mendidik, mengajar, membimbing, melatih, dan menilai. Kelima peran ini sebaiknya dilakukan secara simultan (serentak dalam waktu yang bersamaan), berkesinambangunan, dan terintegrasi antara satu dengan yang lainnya.

\section{Mendidik}

Ada banyak pengertian atau teori tentang mendidik. Menurut Sugianto (n. d.), pendidikan bukan hanya transfer of knowledge, tetapi juga transfer of value. Dengan demikian, berarti pendidikan dapat menjadi sarana untuk membantu umat manusia (Sugianto, n.d.). Sedangkan Darmodiharjo dalam Sodulloh (2010) mengatakan bahwa mendidikan merupakan usaha yang lebih ditujukan kepada pengembangan budi pekerti, hati nurani, semangat, kecintaan, rasa susila, ketakwaan, dan lain-lain. Lalu menurut Wijanarko (2005), mendidik adalah menyampaikan pengajaran, norma-norma dan nilainilai hidup, aturan, dan hukum. Pandangan Wijanarko ini kemudian dipertegaskan lagi oleh Waini Rasyidin dalam tulisannya tentang Pedagogik Kritis, menguraikan pengertian mendidik sebagai kegiatan membimbing pertumbuhan anak, jasmani dan rohaninya dengan sengaja bukan saja untuk kepentingan pengajaran sekarang melainkan untuk kehidupan di masa depan (Zahir, 2011).

Berdasarkan beberapa pengertian di atas, mendidik dapat diartikan sebagai proses bimbingan dan pengajaran dalam rangka mengalihkan nilai-nilai, bukan sekedar pengetahuan saja. Mendidik 
merupakan suatu pekerjaan yang dipikul guru untuk mengarahkan peserta didik dalam belajar dan dalam berperilaku yang baik, baik itu di kelas atau di masyarakat. Jika demikian, dosen yang menjalankan tugas mendidik harus memiliki kemampuan-kemampuan tertentu.

Menurut Kartadinata (2009) kemampuan seorang dosen sebagai pendidik sebagai berikut: merancang program pembelajaran yang memfasilitasi penumbuhan karakter sert soft skill, di samping pembentukan penguasaan hard skill, baik yang berdampak langsung dari tindakan pembelajaran maupun berdampak tidak langsung terhadap pembelajaran; mengimplementasi program pembelajaran dengan kewaspadaan penuh (informed responsiveness) terhadap peluang untuk mengoptimalkan dampak instruksional dan dampak pengiring pembelajaran yang dibingkai dengan wawasan kependidikan; mengakses proses dan hasil pembelajaran yang tercapai baik berdampak langsung maupun berdampang pengiring; memanfaatkan hasil asesmen terhadap proses dan hasil pembelajaran untuk melakukan perbaikan pengelolaan pembelajaran secara berkelanjutan.

\section{Mengajar (Membelajarkan)}

Tugas mengajar seorang dosen selalu dikaitkan dengan metode yang dipakai dalam pembelajaran. Metode adalah salah satu unsur dalam proses pembelajaran. Diharapkan seorang dosen dalam mengajar dapat memperkaya metodologi pembelajaran dan memberikan berbagai metode pembelajaran yang efektif. Dalam pembelajaran, seorang dosen dituntut memiliki paradigma yang benar, khususnya paradigma tentang belajar, membelajarkan, dan mahasiswa. Paradigma atau cara pandang akan berimplikasi langsung dalam pembelajaran, baik berkaitan dengan cara seorang dosen memerankan diri dalam pembelajaran maupun memosisikan mahasiswa dalam proses pembelajaran.

Dewasa ini ada banyak paradigma atau sudut pandang yang dianut dalam pendidikan. Salah satu paradigma yang berkembangan sekarang ini adalah paradigma kosntruktivistik. Menurut paradigma ini, pengetuhan itu temporer, nonobjective, selalu berubah, dan tidak menentu. Belajar merupakan penyusunan pengetahuan dari pengalaman konkret, aktivitas kolaboratif, dan refleksi serta interpretasi.

Untuk mendukung paradigma, diperlukan alat yaitu mind yang berfungsi untuk menginterpretasi peristiwa, objek, atau perspektif yang ada dalam dunia nyata sehingga makna yang dihasilkan bersifat unik dan individualistis. Di sini mengajar menjadi sebuah upaya untuk menata lingkungan agar mahasiswa termotivasi dalam menggali makna serta menghargai ketidakmenentuan.

Dalam proses pembelajaran ini, kebebasan mahasiswa menjadi hal yang esensial. Kegagalan atau keberhasilan kemampuan atau ketidakmampuan dilihat sebagai interpretasi yang berbeda yang perlu dihargai. Kebebasan dipandang sebagai penentu keberhasilan belajar. Mahasiswa merupakan subjek yang harus mampu menggunakan kebebasan untuk melakukan pengaturan diri dalam belajar. Kontrol belajar dipegang oleh mahasiswa. Metode pembelajaran seperti berpusat pada mahasiswa sendiri.

Paradigma ini berpengaruh terhadap strategi atau cara dosen melaksanakan pembelajaran. Misalnya, penyajian isi menekankan pada penggunaan pengetahuan bermakna menggunakan metode induktif. Aktivitas belajar mahasiswa lebih banyak didasarkan pada data primer dan bahan manipulatif dengan penekanan pada keterampilan berfikir kritis. Pembelajaran menekankan pada proses bukan langsung pada hasil. Namun dalam mengajar, seorang dosen harus memiliki komitmen yang kuat. Komitmen menjadi daya untuk mempertahankan paradigma dan cara pelaksanaan mengajar atau membelajarkan mahasiswa. Jika seorang dosen memiliki tiga kekuatan ini yaitu paradigma, cara, dan komitmen akan mampu menumbuhkan karakter mahasiswa. Dosen menjadi aktor untuk membentuk karakter mahasiswa. Sementara, perguruan tinggi menjadi laboratorium karakter. 


\section{Membimbing}

Lickona (2012) mengatakan bahwa dosen sebenarnya menjadi model yang secara aktif menjadi contoh dalam melakukan kegiatan belajar efektif seperti mencontohkan penggunaan strategi belajar atau cara mengungkapkan pemikiran secara verbal yang dapat membantu proses konstruksi pengetahuan. Maka dalam membimbing para mahasiswa seorang dosen harus mampu menerapkan diri atau menjadikan diri sebagai orang yang ditiru atau digugu. Keteladanan dan budi pekerti seorang dosen akan memberikan pengaruh yang kuat terhadap para mahasiswa yang dibimbing.

\section{Melatih}

Seorang dosen dapat berperan sebagai pelatih. Dalam melatih seorang dosen menjadi pemicu atau pendorong, stimulus, memacu para mahasiswa untuk memaksimalkan potensi otak kanan dan otak kiri. Dosen bertugas memberikan petunjuk, umpan balik, dan pengarahan terhadap upaya belajar mahasiswa. Mahasiswa sedapat mungkin tetap mencoba memecahkan masalahnya sebelum memperoleh masukan dari dosen.

\section{Menilai}

Inti pokok menilai atau mengevaluasi adalah upaya untuk mengetahui sejauh mana proses pembelajaran telah mencapai sasaran. Kegiatan evaluasi atau menilai berorientasi pada kegiatan mengukur dan menilai sejauh mana program pembelajaran sudah tercapai. Kegiatan evaluasi yang dirancang secara sistematis dan komprehensif akan memberikan gambar sejauh mana proses pembelajaran memberi hasil belajar pada diri siswa. Oleh karena itu, perlu dirancang alat evaluasi proses pembelajaran yang valid, mendidik, berorientasi pada kompetensi, adil, terbuka, berkesinambungan, menyeluruh, dan bermakna (Harsanto, 2007). Lebih lanjut, Harsanto (2007) mengungkapkan beberapa komponen penilaian atau evaluasi dalam pendidikan karakter antara lain sebagai berikut. Pertama, perilaku dalam proses pembelajaran mencakup sikap dan tindakan mahasiswa terhadap sesama rekan mahasiswa dan dosen. Sikap dan tindakan yang dinilai adalah sikap dan tindakan yang mengacu pada nilai-nilai yang terkandung dalam materi pembelajaran. Beberapa teknik penilai untuk mengungkapkan komponen ini adalah observasi, pertanyaan langsung, pertanyaan tidak langsung, portofolio, dan penilaian diri.

Kedua, kesungguhan dan kedisiplinan mahasiswa dalam mengikuti pembelajaran. Komponen ini mencakup aspek: kehadiran dalam pembelajaran, ketepatan waktu mengikuti pembelajaran, ketepatan waktu mengumpulkan tugas, frekuensi dan kualitas bertanya, frekuensi dan kualitas berpendapat, dan frekuensi berkonsultasi di luar jam perkuliahan dalam rangka pengayaan dan konsultasi akademik, dan kreativtas penalaran yang ditunjukkan dalam kegiatan atau karya yang berkaitan dengan pembelajaran. Teknik untuk menilai menggunakan observasi, pertanyaan langsung, pertanyaan tidak langsung, portofolio, dan penilain diri.

Ketiga, prestasi mahasiswa yang terdiri dari prestasi akademik dan prestasi nonakademik. Untuk mengukur kedua aspek tersebut dapat digunakan teknik penilaian tes dan portofolio.

\section{SIMPULAN}

Berdasarkan berbagai uraian tersebut, peran dosen dalam membentuk karakter mahasiswa merupakan aspek yang sangat penting. Dosen tidak hanya mengajar tetapi juga mendidik, membimbing, melatih, dan juga memberikan evaluasi atau penilaian terhadap berbagai pembelajaran 
di kelas. Di sini dosen merupakan salah satu unsure utama selain mahasiswa, dan masyarakat akademik di perguruan tinggi.

Tugas pokok dosen adalah melaksanakan Tri Dharma Perguruan Tinggi, yaitu kegiatan pendidikan, penelitian, dan pengabdian kepada masyarakat. Kegiatan-kegiatan ini merupakan inti dari semua aktivitas dosen dalam masyarakat akademik perguruan tinggi.

Dosen yang berperan dalam pendidikan karakter adalah dosen yang mampu melihat profesinya sebagai panggilan jiwa. Ia melaksanakan berbagai tugasnya yang terangkum dalam tridharma perguruan tinggi. Di sisi lain, seorang dosen sebagaimana seorang guru, merupakan actor utama dalam pembelajaran. Peran dosen dalam keberhasilan internalisasi pendidikan karakter kepada para mahasiswanya adalah kunci utama. Faktor lain adalah seperti kurikulum, budaya, kegiatankegiatan spontan, hanya merupakan pendukung bagi dosen.

Pendidikan karakter di perguruan tinggi harus dilakukan melalui pembiasaan kehidupan keseharian di kampus, sehinggai menjadi budaya kampus. Bentuk nyata tampak dalam kegiatan mahasiswa seperti olahraga, karya tulis, kesenian, dan sebagainya. Strategi lain adalah mewujudkan budaya akademik yang merupakan manifestasi dari nilai-nilai luhur total dalam budaya akademik. Wujudnya dalam bentuk kegiatan kurikuler, kokurikuler, atau kegiatan mahasiswa yang berbasi pada bidang profesi yang dipelajari, dan ekstrakurikuler.

Secara lengkap peran dosen dalam menginternalisasikan nilai-nilai luhur atau pendidikan karakter di perguruan tinggi adalah menetapkan tujuan, sasaran, dan target yang jelas dan konkret; perlu kerja sama semua pihak antara perguruan tinggi, orangtua mahasiwa, dan juga dosen; menyadarkan pada semua dosen akan peran penting dan tanggung jawab dalam keberhasilan melaksanakan dan mencapai tujuan pendidikan karakter; kesadaran para dosen akan perlunya hidden curriculum merupakan instrumen penting dalam pengembangan karakter mahasiswa; keteladan dosen dalam pendidikan karakter. Keteladanan menjadi komunikasi yang efektif dalam mengembangkan nilai-nilai luhur dalam diri mahasiswa; dosen perlu menekankan daya kritis pada mahasiswa; membangun budaya perguruan tinggi yang menghargai nilai-nilai luhur atau karakter bangsa; dan melakukan pembiasaan dalam kehidupan sehari-hari di kampus kemudian membentuk budaya kampus.

\section{DAFTAR PUSTAKA}

Harsanto, R. (2007). Pengelolaan Kelas yang Dinamis, Paradigma Baru Pembelajaran Menuju Kompetensi Siswa. Yogyakarta: Kanisius.

Kartadinata, S. (2009). Terapi dan Pemulihan Pendidikan. Bandung: UPI.

Lickona, T. (2012). Educating for Character. Jakarta: Bumi Aksara.

Sadulloh, U., dkk. 2010. Pedagogic (Ilmu Mendidik). Bandung: Alfebata

Santoso, D. (20 Mei 2011). Pendidikan Karakter di Perguruan Tinggi. Diakses 2 September 2013 dari http://suaraguru.wordpress.com/2011/05/20/pendidikan-karakter-di-perguruan-tinggi/

Sugianto, E. (n. d.). Perbedaan Mendidik dan Mengajar. Diakses 2 September 2013 dari http://www.naqsdna.com/perbedaan-mendidik-dan-mengajargg.html. 
Wibowo, A. (2013). Pendidikan Karakter di Perguruan Tinggi Membangun Karakter Ideal Mahasiswa di Perguruan Tinggi. Yogyakarta: Pustaka Pelajar.

Wijanarko, J. (2005). Mendidik Anak: Untuk Meningkatkan Kecerdasan Emosional dan Spiritual. Jakarta: Gramedia Pustaka Utama.

Zahir, A. (11 September 2011). Pengertian Pendidikan, Mendidik, Pembelajaran, \& Mengajar. Diakses 2 September 2013 dari http://hepimakassar.wordpress.com/tag/mengajar/

Zamroni. (23 Mei 2011). Strategi dan Model Implementasi Pendidikan Karakter di Sekolah. Makalah pada Seminar Pendidikan Karakter di Sekolah di Magelang. 